\title{
SENSITIVITY OF DIAGNOSTIC TESTS FOR DRY EYE IN PATIENTS WITH BLEPHAROSPASM
}

\author{
Dubravka Biuk ${ }^{1}$, Maja Vinković ${ }^{1}$, Suzana Matić ${ }^{1}$, Mario Bradvica $^{1}$, Egon Biuk $^{2}$ and Trrtka Benašić ${ }^{1}$ \\ ${ }^{1}$ Department of Ophthalmology, ${ }^{2}$ Department of Orthopedic Surgery, Osijek University Hospital Centre, \\ School of Medicine, Josip Juraj Strossmayer University of Osijek, Osijek, Croatia
}

\begin{abstract}
SUMMARY - The aim of the study was to evaluate diagnostic tests for keratoconjunctivitis sicca (Schirmer test, tear break-up time (TBUT) test, and corneal staining with fluorescein and lissamine green dye) in patients with blepharospasm. This prospective study included 60 female patients older than 40 with blepharospasm, divided into two groups according to clinical symptoms. For fluorescein test, the surface under the ROC curve was 1.0 with standard error (SE) 0 and $95 \%$ confidence interval (95\% CI) 0.940-1.0; for Schirmer test, the surface under the ROC curve was 0.817 with SE 0.0555 and $95 \% \mathrm{CI}$ 0.696-0.905; for lissamine green test, the surface under the ROC curve was 0.813 with SE 0.056 and $95 \%$ CI $0.691-0.902$; and for TBUT test, the surface under the ROC curve was 0.772 with SE 0.061 and $95 \%$ CI 0.645-0.870. According to the results of ROC curve, which determines the sensitivity and specificity of normal values, comparison of diagnostic tests for keratoconjunctivitis sicca used in this study showed that fluorescein test had the best sensitivity and specificity. Schirmer test should be avoided in patients with blepharospasm because its results are influenced by frequent blinking and are not appropriate for study interpretation. Despite the pathologic values of TBUT test (numerically), this test is still acceptable for patients with blepharospasm because its interval takes more time than the interval between two blinks.
\end{abstract} Croatia

Key words: Staining and labeling; Blepharospasm, Fluorescein; Lissamine green dye; ROC curve;

\section{Introduction}

Blepharospasm is a periodical, involuntary contraction of the orbicular muscle of eye that often remains unrecognized (50\% of cases in 5 years on up to 3 examinations) ${ }^{1}$ and very often confused with dry eye ${ }^{2}$. Blepharospasm patients complain of sand feeling in their eyes, eye dryness, and photophobia ${ }^{3-5}$. On slit lamp examination, it is possible to get normal finding of the anterior eye segment or symptoms of chronic conjunctivitis, keratitis or iritis.

The most widely used diagnostic tests for tear film examination are tear break-up time (TBUT) test, cor-

Correspondence to: Mario Bradvica, $M D, P h D$, Department of Ophthalmology, Osijek University Hospital Centre, Europska avenija 14-16, HR-31000 Osijek, Croatia

E-mail: mario.bradvica@vip.hr

Received November 24, 2016, accepted May 8, 2017 neal and conjunctival staining with fluorescein, rose bengal and lissamine green dye, Schirmer test, tear film osmolarity test and impression cytology.

Schirmer test is the objective test most frequently and longest (more than 100 years) ${ }^{6}$ used in dry eye diagnosis, but as it is not standardized ${ }^{7,8}$, it is inaccurate and it cannot be repeated because it causes reflex secretion with its invasiveness ${ }^{9}$, measures only tear production $^{10}$, and provides no information on tear evaporation ${ }^{11}$. However, because of its low price and easy performance, it is the most frequently used dry eye lacrimal secretory function test ${ }^{12}$.

Tear break-up time fluorescein test is widely accepted in dry eye diagnosis and is considered more reliable than Schirmer test as it can be repeated ${ }^{13}$, and is minimally invasive. With this test, it is possible to get information on tear evaporation. It is necessary to repeat the measurement at least three times and the re- 
sults should be similar. When there are significant differences between measurements, the result should be interpreted as "TBUT unreliable". In addition, there should be no asymmetry between the results obtained on both eyes. Such results probably reflect unilateral secondary cause (for example, bacterial or viral infection, allergy ${ }^{14-16}$. When TBUT is shorter than the interval between two blinks, it is considered normal for the person when awake ${ }^{11}$, since the healthy eye frequency of blinking is 10-12 times per minute.

The lissamine green dye that stains degeneratively changed, dead cells and mucous fibrils has been used in the evaluation of conjunctival vitality. Typical staining of bulbar conjunctiva has the shape of two triangles with the base on the limbus ${ }^{16}$. It is important to note that staining should not be performed after the use of topical anesthetics because of the possible false-positive results.

Conjunctival and corneal epithelial erosions are stained with fluorescein dye (fluorescein invades the sites of disruption between cell junctions). Pathognomonic staining of epithelial erosions in dry eye is bilateral and symmetric, punctate all around the cornea, corneal at six o'clock, and conjunctival at the site of palpebral rim.

Because of frequent blinking in blepharospasm, we wondered whether particular diagnostic tests would prove valuable in the diagnosis of dry eye in patients with blepharospasm due to their questionable use (e.g., TBUT, Schirmer test, etc.) or would yield false-negative results (such as corneal fluorescein test).

\section{Materials and Methods}

This prospective study conducted from January 2004 until December 2009 included 60 female patients older than 40 and divided into two groups according to their clinical symptoms. The first group included patients with grade I or II blepharospasm with predominating symptomatology of dry eye, also serving as control group. The second group included patients with grade III or IV blepharospasm requiring medical therapy. All patients that needed medical therapy were treated, after obtaining their informed consent, with botulinum neurotoxin type A injection, which is today considered the therapy of choice ${ }^{17,18}$. The patients with glaucoma or ocular hypertension prior to or acquired during the study period were ex- cluded due to constant use of topical antiglaucoma medication because of the possible occurrence of ocular surface defects. Patients having undergone surgical procedures on the anterior or posterior segment of the eye, as well as those in whom botulinum neurotoxin type A was contraindicated were also excluded from the study.

In dry eye diagnosis, we used the following special tests:

\section{Schirmer test}

A method of double washing up (double-void technique) with measurement of tear film water component. Result interpretation: $>10 \mathrm{~mm}$ - normal secretion; 5-10 $\mathrm{mm}$ - borderline result; $<5 \mathrm{~mm}$ - probable hyposecretion dry eye; and $<3 \mathrm{~mm}$ - hyposecretion dry eye.

\section{Tear break-up time (TBUT)) test}

Tear film stability measurement - relevant finding is development of multiple and diffuse black spots or lines in the tear film ${ }^{19-22}$. Result interpretation: interval TBUT test shorter than $10 \mathrm{~s}-$ dry eye diagnosis is considered; and interval TBUT test shorter than $5 \mathrm{~s}-$ dry eye diagnosis is highly probable.

\section{Ocular surface staining with 1\% fluorescein solution}

The National Eye Institute (NEI)/Industry Workshop scale was used for evaluation of the amount of ocular surface staining with fluorescein ${ }^{23}$. The cornea was divided into five and conjunctiva into three areas, and staining in each particular area was evaluated from 0 to 3 up to the maximum of 15 points.

Assessment of conjunctival vitality by lissamine green staining, which stains degenerative, dead cells and mucous fibrils. Staining profile typical for bulbar conjunctiva is triangle shaped with its base on the limbus ${ }^{16}$.

Van Bijsterveld score ${ }^{10}$ was used on result interpretation. The interpalpebral region is divided into three areas: temporal conjunctiva, nasal conjunctiva, and central cornea. Each of these areas is further graded into three stages: low, moderate, and severe. Total score is calculated for each eye, maximum score is 9. A score of 3.5 or more indicates keratoconjunctivitis sicca.

\section{Statistics}

The mean values of continuous variables were expressed by arithmetic mean and standard deviation for 
normally distributed variables, and by median and range for unequally distributed variables. Nominal indicators were shown by frequency distribution according to groups and share. Mann-Whitney test was used to determine differences between two independent samples. The level of significance was set at $\alpha=0.05$.

\section{Results}

During the study, the following tests were performed on our subjects: fluorescein staining test on both eyes, lissamine dye staining test on both eyes, TBUT test on both eyes, and Schirmer test on both eyes (Table 1). Differences in the measured values were significant for all parameters except for fluorescein test for left eye. There was no statistically significant difference in the measured values of ophthalmological tests according to age groups (Table 2).

Table 1. Basic measures and distribution of parameters in both groups

\begin{tabular}{|l|l|l|l|}
\hline \multirow{2}{*}{ Parameter } & $\begin{array}{l}\text { Control } \\
\text { group }\end{array}$ & $\begin{array}{l}\text { Intervention } \\
\text { group }\end{array}$ & \multirow{2}{*}{$\mathrm{p}^{*}$} \\
\cline { 2 - 4 } & $\begin{array}{l}\text { Median } \\
(25 \%-75 \%)\end{array}$ & $\begin{array}{l}\text { Median } \\
(25 \%-75 \%)\end{array}$ & \\
\hline FL test right eye & $3(2.75-3)$ & $4(4-4)$ & $<0.001$ \\
FL test left eye & $4(4-4)$ & $4(4-4)$ & 0.078 \\
TBUT right eye & $3.5(3-4)$ & $2.5(2-3)$ & 0.001 \\
TBUT left eye & $4(3-4)$ & $2.5(2-3)$ & $<0.001$ \\
$\begin{array}{l}\text { Lissamine green } \\
\text { test }\end{array}$ & $7(5.75-7)$ & $5(4-5.25)$ & $<0.001$ \\
$\begin{array}{l}\text { Schirmer test } \\
\text { for both eyes }\end{array}$ & $2(1-2)$ & $1(1-1)$ & $<0.001$ \\
\hline
\end{tabular}

*Mann-Whitney test; FL = fluorescein test; TBUT = tear break-up time test

Table 2. Significance of ophthalmologic tests according to groups of subjects

\begin{tabular}{|l|l|l|}
\hline & $\begin{array}{l}\text { Control group } \\
\mathrm{p}^{*}\end{array}$ & $\begin{array}{l}\text { Intervention group } \\
\mathrm{p}^{*}\end{array}$ \\
\hline FL test & 0.792 & 0.999 \\
TBUT test & 0.297 & 0.074 \\
Lissamine test & 0.031 & 0.974 \\
Schirmer test & 0.104 & 0.988 \\
\hline
\end{tabular}

*Kruskal Wallis test; FL = fluorescein test; $\mathrm{TBUT}=$ tear break-up time test
The validity of fluorescein test was assessed by the Receiver Operating Characteristic (ROC) curve, where the sensitivity and specificity based on normal values are determined. The surface under the curve is the measure of test accuracy. For fluorescein test, the surface under the ROC curve was 1.0, with standard error (SE) 0 and $95 \%$ confidence interval $(95 \% \mathrm{CI})$ $0.940-1.0$. Since the surface under the curve was in the 0.9-1.0 interval, this test was considered an excellent test for differentiating control group from intervention group of patients. TBUT test yielded the area under the ROC curve of 0.772 with SE 0.061 and $95 \%$ CI $0.645-0.870$. Since the area under the ROC curve measures the accuracy of the test, the value of 0.772

Table 3. Statistical indicators for ROC curves of each test

\begin{tabular}{|l|l|l|l|}
\hline & $\begin{array}{l}\text { Area under } \\
\text { the curve }\end{array}$ & $\begin{array}{l}\text { Standard } \\
\text { error }\end{array}$ & $\begin{array}{l}95 \% \text { Confidence } \\
\text { interval }\end{array}$ \\
\hline $\begin{array}{l}\text { FL test } \\
\text { TBUT test }\end{array}$ & 1.0 & 0 & $0.940-1.0$ \\
$\begin{array}{l}\text { Schirmer } \\
\text { test }\end{array}$ & 0.817 & 0.061 & $0.645-0.870$ \\
$\begin{array}{l}\text { Lissamine } \\
\text { green test }\end{array}$ & 0.813 & 0.055 & $0.696-0.905$ \\
\hline
\end{tabular}

$\mathrm{FL}=$ fluorescein test; $\mathrm{TBUT}=$ tear break-up time test

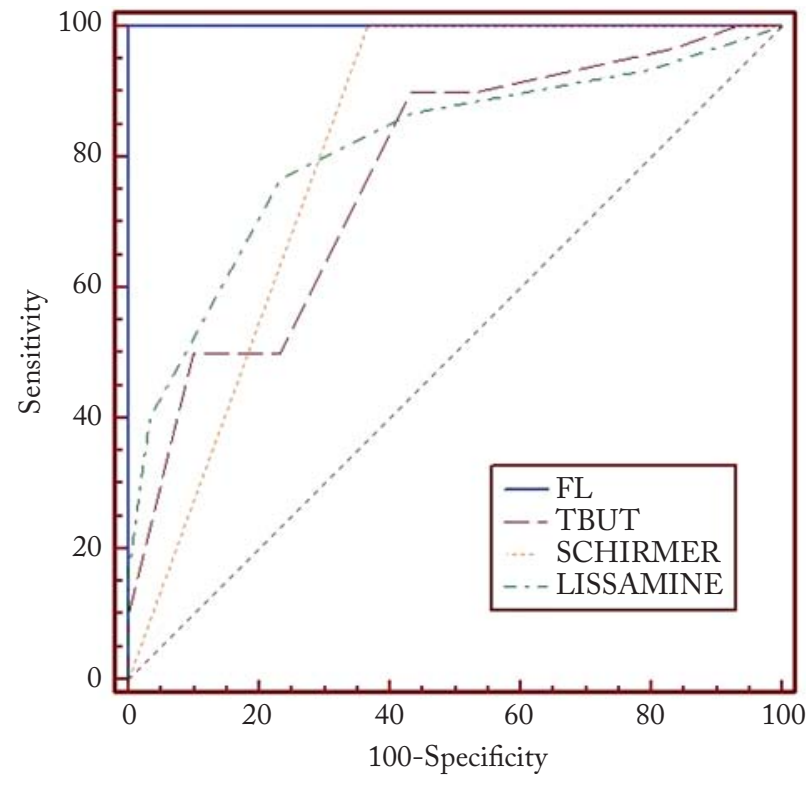

$\mathrm{FL}=$ fluorescein test; $\mathrm{TBUT}=$ tear break-up time test

Fig. 1. Comparison of specificity and sensitivity of ophthalmologic tests - ROC curve. 
Table 4. Border criterion values of ophthalmologic tests

\begin{tabular}{|l|l|l|l|l|l|}
\hline & Value & FL test & TBUT test & Schirmer test & $\begin{array}{l}\text { Lissamine } \\
\text { green test }\end{array}$ \\
\hline Border criterion value & 3.5 & 3 & 1 & 5 \\
\hline Sensitivity & 100 & 90 & 100 & 76.67 \\
\hline Specificity & 100 & 56.67 & 63.33 & 76.67 \\
\hline \multirow{2}{*}{ Probability ratio } & Positive & 0 & 2.08 & 2.73 & 3.29 \\
\cline { 2 - 6 } & Negative & 0 & 0.18 & 0 & 0.30 \\
\hline \multirow{2}{*}{ Predictive value } & Positive & 100 & 67.5 & 73.2 & 76.7 \\
\cline { 2 - 6 } & Negative & 100 & 85.0 & 100 & 76.7 \\
\hline
\end{tabular}

$\mathrm{FL}=$ fluorescein test; $\mathrm{TBUT}=$ tear break-up time test

Table 5. Statistical significance of ROC curves between ophthalmologic tests used

\begin{tabular}{|l|l|l|}
\hline Tests compared & $\mathrm{Z}$ & $\mathrm{p}$ \\
\hline FL test - TBUT test & 3.742 & $<\mathbf{0 . 0 0 1}$ \\
FL test - Schirmer test & 3.302 & $\mathbf{0 . 0 0 1}$ \\
FL test - Lissamine green test & 3.341 & $\mathbf{0 . 0 0 1}$ \\
TBUT test - Schirmer test & 0.581 & 0.561 \\
TBUT test - Lissamine green test & 0.555 & 0.579 \\
Schirmer test - Lissamine green & 0.051 & 0.959 \\
test
\end{tabular}

$\mathrm{FL}=$ fluorescein test; $\mathrm{TBUT}=$ tear break-up time test

indicated TBUT to be a mediocre test for group differentiation. Schirmer test yielded the area under the ROC curve of 0.817 with SE 0.0555 and 95\% CI 0.696-0.905. Lissamine green test yielded the area under the ROC curve of 0.813 with SE 0.056 and 95\% CI 0.691-0.902 (Table 3, Fig. 1).

Besides specificity and sensitivity, for every ophthalmologic test there are defined border criterion (cut-off) values and values of criterion predictor (the ratio of probability that the result will be positive or negative and positive and negative predictive values) (Table 4). The probability ratio tells us what is the probability of the expected outcome of the diagnostic test in the control group of patients as compared with the intervention group.

Predictive value shows how many times (\%) the value measured with the test was the real value. It was highest in fluorescein test and lowest in TBUT test. All these data proved that fluorescein test had highest sensitivity and TBUT test lowest sensitivity (Fig. 1).
An overview of statistical significance among ROC curves for all ophthalmologic tests is shown in Table 5.

\section{Discussion}

The study included only female patients since the disease is more common in female population (female to male ratio, 3:1). Epidemiological studies report that dry eye, which is present in almost all blepharospasm patients, is also more common in female population, especially postmenopausal ${ }^{24}$ and elderly ${ }^{25-28}$ women. In order to avoid the possible differences in result interpretation, which are caused by hormonal differences in dry eye symptoms, only female subjects were included in the study.

Patients suffering from glaucoma were excluded from the study, as it is well known that long-term use of antiglaucoma drugs may change ocular surface and tear film function. These changes can be caused by the drugs themselves, preservatives in commercial preparations, or by long duration of local therapy. The clinical effect on ocular changes is unknown ${ }^{29-34}$. Herreras et al. showed that $66 \%$ of patients having used local timolol therapy for 25 months and more had pathologic Schirmer test, while TBUT was shorter than 10 $s$ in $95 \%$ of cases $^{34}$.

Dry eye diagnosis is usually based on history data and diagnostic tests such as TBUT, Schirmer test, rose bengal (lissamine green) or fluorescein dye staining of conjunctiva and cornea, impression cytology, punctate epithelial keratopathy, and filamentous keratitis. Although simple to perform, impression cytology is not widely spread as a diagnostic method in clinical practice in dry eye diagnosis. It requires cooperation with 
cytologists and it is not practical in clinical work, probably because almost all dry eye patients also have squamous metaplasia.

Khanal et al. ${ }^{33}$ carried out a study in which they evaluated individual diagnostic tests in the diagnosis of dry eye. In addition to standard tests (Schirmer test, TBUT, fluorescein and rose bengal test), they also performed specific measurements of osmolarity and evaporation, and meibomian gland function analysis. The authors found the measurement of osmolarity to be the best test for the diagnosis of dry eye, although Schirmer test is the most widely used test (for over 100 years). However, the former test is very expensive and therefore not widely usable in clinical practice.

Schirmer test certainly has its place in the diagnosis of dry eye, but the person who performs it needs to know what is actually measured by this test, i.e. only and exclusively the aqueous component of tear film. Generalizing the results of the entire tear film is completely wrong and this test cannot be used alone in the diagnosis of dry eye. In addition, in patients with blepharospasm, this test should be avoided, as it is difficult to perform it properly because of the nature of the disease. Schirmer test, although the oldest test used in dry eye diagnosis, should be avoided in patients with benign essential blepharospasm because of questionable performing it correctly. The test measures only tear film water component and if there is suspicion of hyposecretion dry eye (for example, a combination of benign essential blepharospasm and Sjögren's syndrome), it should be performed during the asymptomatic stage of the disease, but not right after botulinum toxin application because it also influences tear secretion.

In our study, all subjects had the result of Schirmer test above $5 \mathrm{~mm}$, suggesting that these patients did not have hyposecretion dry eye. Schirmer test result between 5 and $10 \mathrm{~mm}$ (borderline result) was recorded in $63.3 \%$ of control group and $3.3 \%$ of intervention group subjects. It is interesting to note that $96.7 \%$ of the intervention group subjects had Schirmer test result above $10 \mathrm{~mm}$, indicating that performing this test in the intervention group was questionable. Schirmer test is correctly performed only when the subject is calm and does not talk or move the eyeballs under closed eyelids, which is practically impossible in blepharospasm patients, especially those with grade III or IV.

Every form of dry eye disease is associated with increased tear osmolarity and decreased tear film stabil- ity. Therefore, measuring tear film stability is highly relevant in dry eye diagnosis, as also demonstrated in this study. Unfortunately, TBUT does not have good reputation because of its unreliability and high result variability, and results are neither reproducible nor comparable. However, the main reason is that the test is performed in many ways that have not been standardized and therefore the results are incomparable. TBUT test can be performed with or without fluorescein. Fluorescein is used although it can destabilize tear film ${ }^{21,35,36}$. However, with careful instillation of fluorescein in the conjunctival bag and avoiding reflex secretion induction, this influence on tear film can be avoided $^{37}$. Difference of TBUT results between the two groups was statistically significant. Despite pathologic TBUT results in both groups, especially in the intervention group, it was concluded that these results were normal. Ousler et al. think that if TBUT is shorter than the interval between two blinks, TBUT for that person is normal when awake, considering that healthy eye frequency of blinking is 10-12 times per minute $^{16}$.

Dry eye diagnosis also uses $1 \%$ fluorescein dye staining that stains surface epithelial erosions, and bengal rose and lissamine green dye staining that stains degeneratively changed or dead epithelial cell $\mathrm{s}^{21,36,38}$. Deficiency of these tests is that they show superficial eye erosions, they are not appropriate for early dry eye disease detection, and cannot differentiate dry eye from other conditions that have ocular surface staining ${ }^{38-40}$. In this study, fluorescein and lissamine green were used for staining the surface of the eye. Khurana et al. report that staining with bengal red and lissamine green gives comparable results but staining with lissamine green is less irritating to patients ${ }^{38}$. These results were also confirmed by Manning et al., who compared tolerability of these dyes in patients and characteristics of ocular surface staining in keratoconjunctivitis sicca ${ }^{39}$.

Comparing diagnostic tests for keratoconjunctivitis sicca used in this study according to ROC curve that determines the sensitivity and specificity based on normal values, we found fluorescein test to have highest and TBUT test lowest sensitivity and specificity. We could explain low sensitivity and specificity of TBUT test with difficulty to perform it correctly because of the nature of the disease. Despite pathologic TBUT test results (numerically), they are not considered to be a problem in patients with benign essential 
blepharospasm (especially grade III or IV) because they are often longer than the interval between two blinks.

Schirmer test should be avoided in patients with blepharospasm because frequent blinking affects the test reliability and hence we could not demonstrate that it would have an impact on the disease prognosis and therapy protocol. Despite the pathologic values of TBUT test (numerically), this test is still acceptable for patients with blepharospasm because its interval takes more than the interval between two blinks.

\section{References}

1. Logroscino G, Livrea P, Anaclerio D, et al. Agreement among neurologists on the clinical diagnosis of dystonia at different body sites. J Neurol Neurosurg Psychiatry. 2003;74(39):348-50. PubMed PMID: 12588923; PubMed Central PMCID: PMC1738354

2. Tseng SCG, Tsubota K. Important concepts for treating ocular surface and tear disorders. Am J Ophthalmol. 1997;124: 825-35. PMID: 9402829

3. Jankovic J, Ford J. Blepharospasm and orofacial-cervical dystonia: clinical and pharmacological findings in 100 patients. Ann Neurol. 1983;13(4):402-11. PubMed:6838174

4. Grandas F, Elston J, Quinn N, Marsden CD. Blepharospasm: a review of 264 patients. J Neurol Neurosurg Psychiatry. 1988;51(6):767-72. PMID: 3404184 PMCID: PMC1033145

5. Elston JS, Marsden CD, Grandas F, Quinn NP. The significance of ophthalmological symptoms in idiopathic blepharospasm. Eye (Lond). 1988;2(Pt 4):435-9. PMID: 3253136

6. Cho P, Yap M. Schirmer test. I. A review. Optom Vis Sci. 1993;70(2):152-6. PMID: 8446379

7. Wright JC, Merger GE. A review of the Schirmer test for tear production. Arch Ophthalmol. 1962;67:564-5.

8. Lamberts DW. Keratoconjunctivitis sicca. In: Smolin G, Thoft RA, eds. The Cornea: Scientific Foundations and Clinical Practice. Boston: Little Brown; 1987:387-405.

9. Schaumberg DA, Sullivan DA, Dana MR. Epidemiology of dry eye syndrome. Adv Exp Med Biol. 2002;506(Pt B):989-98. PMID: 12614022

10. van Bijsterveld OP. Diagnostic tests in the sicca syndrome. Arch Ophthalmol. 1969;82(1):10-4.

11. Sommer A. Nutritional Blindness. Xerophthalmia and Keratomalacia. Oxford: Oxford University Press, 1982. doi: http:// dx.doi.org/10.1016/0039-6257(82)90074-1

12. Tseng SC. Staging of conjunctival squamous metaplasia by impression cytology. Ophthalmology. 1985;92(6):728-33. PMID: 3897935

13. Abelson MB, Oursler GW $3^{\text {rd }}$, Nally LA, Welch D, Krenzer K. Alternative reference values for tear film break up time in nor- mal and dry eye populations. Adv Exp Med Biol. 2002;506 (Pt B):1121-5. PMID: 12614039

14. CedarstaffTH, Tomlinson A. Human tear volume, quality and evaporation: a comparison of Schirmer, tear break-up time and resistance hygrometry techniques. Ophthalmic Physiol Opt. 1983;3(3):239-45. PMID: 6646757

15. Patel S, Murray D, McKenzie A, Shearer DS, McGrath BD. Effects of fluorescein on tear breakup time and on tear thinning time. Am J Optom Physiol Optics. 1985;62(3):188-90. doi: 10.4103/0300-1652.182071; PMCID: PMC4872486

16. Oursler GW, Emory TB, Welch D, Abelson MB. Factors that influence the inter-blink interval (IBI) as measured by the ocular protection index (OP). IOVS. 2002;43(13):56.

17. Scott $A B$. Botulinum toxin injection into extraocular muscles as an alternative to strabismus surgery. Ophthalmology. 1980; 87:1044-9. PMID: 7243198

18. Scott AB, Kennedy RA, Stubbs HA. Botulinum A toxin injection as a treatment for blepharospasm. Arch Ophthalmol. 1985;103:347-50. PMID: 3977705

19. Welsh D, Oursler G. An approach to a more standardized method of evaluating tear film break-up time. Invest Ophthalmol Vis Sci. 2003;24:85.

20. Madden RK, Paugh JR, Wang C. Comparative study of two non-invasive tear film stability techniques. Curr Eye Res. 1994; 13(4):263-9. http://dx.doi.org/10.3109/02713689408995787

21. Bron AJ, Evans VE, Smith JA. Grading of corneal and conjunctival staining in the context of other dry eye tests. Cornea. 2003;22(7):640-50.

22. Johnson ME, Murphy PJ. The Effect of instilled fluorescein solution volume on the values and repeatability of TBUT measurements. Cornea. 2005;24(7):811-7.

23. Lemp MA. Report of the National Eye Institute/Industry Workshop on Clinical Trials in Dry Eyes. CLAO J. 1995; 21(4):221-32.

24. Yazdani C, McLaughlin T, Smeeding JE, Walt J. Prevalence of treated dry eye disease in a managed care population. Clin Ther. 2001;23(10):1672-82. https://doi.org/10.1016/S01492918(01)80136-3

25. Moss SE, Klein R, Klein BE. Prevalence of and risk factors for dry eye syndrome. Arch Ophthalmol. 2000;118(9):1264-8. doi:10.1001/archopht.118.9.1264

26. Lin PY, Tsai SY, Cheng CY, Liu JH, Chou P, Hsu WM. Prevalence of dry eye among an elderly Chinese population in Taiwan: the Shihpai Eye Study. Ophthalmology. 2003;110(6): 1096-101. Epub 2003/06/12.https://doi.org/10.1016/S01616420(03)00262-8

27. Schaumberg DA, Sullivan DA, Dana MR. Epidemiology of dry eye syndrome. Adv Exp Med Biol. 2002;506:989-98.

28. Shimazaki J, Hanada K, Yagi Y, et al. Changes in ocular surface caused by antiglaucomatous eyedrops: prospective, randomised study for the comparison of $0.5 \%$ timolol and $0.12 \%$ unoprostone. Br J Ophthalmol. 2000;84:1250-4. http://dx.doi.org/ 10.1136/bjo.84.11.1250 
29. Inoue K, Okugawa K, Kato S, et al. Ocular factors relevant to anti-glaucomatous eyedrop-related keratoepitheliopathy. J Glaucoma. 2003;12:480-5.

30. Yalva IS, Gedikoglu G, Karagoz Y, et al. Effects of antiglaucoma drugs on ocular surface. Acta Ophthalmol Scand. 1995;73:246-8. doi: 10.1111/j.1600-0420.1995.tb00277.x

31. Arici MK, Arici DS, Topalkara A, Guler C. Adverse effect of topical antiglaucoma drugs on the ocular surface. Clin Exp Ophthalmol. 2000;28:113-7. doi: 10.1046/j.1442-9071.2000. 00237.x

32. Brandt JD, Wittpwnn JR, Katz LJ, Steinmann WN, Paeth GL. Conjunctival impression cytology in patients with glaucoma using long-term topical medication. Am J Ophthalmol. 1991; 15:297-301. https://doi.org/10.1016/S0002-9394(14)76730-3

33. Khanal S, Tomlinson A, McFadyen A, Diaper C, Ramesh K. Dry eye diagnosis. Invest Ophthalmol Vis Sci. 2008:49(4): 1407-14.

34. Herreras JM, Pastor JC, Calonge M, et al. Ocular surface alteration after long-term treatment with an antiglaucomatous drug. Ophthalmology. 1992;99:1082-8. https://doi.org/ 10.1016/S0161-6420(92)31847-0
35. Sherwood MB, Grierson I, Millar L, Hitchings RA. Longterm morphologic effects of antiglaucoma drugs on the conjunctiva and Tenon's capsule in glaucoma patients. Ophthalmology. 2000;28:327-35. https://doi.org/10.1016/S01616420(89)32888-0

36. Mengher LS, Bron AJ, Tonge SR, Gilbert DJ. A non-invasive instrument for clinical assessment of the pre-corneal tear film stability. Curr Eye Res. 1985;4(1):1-7. http://dx.doi.org/ $10.3109 / 02713688508999960$

37. Nichols KK, Mitchell GL, Zadnik K. The repeatability of clinical measurements of dry eye. Cornea. 2004;23(3):272-85.

38. Khurana AK, Chaudhary R, Ahluwalia BK, Gupta S. Tear film profile in dry eye. Acta Ophthalmol. 1991:69;79-86. doi: 10.1111/j.1755-3768.1991.tb01997.x

39. Manning FJ, Wehrly SR, Foulks GN. Patient tolerance and ocular surface staining characteristics of lissamine green versus rose bengal. Ophthalmology. 1995;102:1953-7. doi: https:// doi.org/10.1016/S0161-6420(95)30769-5

40. Kim J. The use of vital dyes in corneal disease. Curr Opin Ophthalmol. 2000;11(4):241-7.

Sažetak

\title{
OSJETLJIVOST DIJAGNOSTIČKIH TESTOVA ZA SUHO OKO KOD BOLESNIKA S BLEFAROSPAZMOM
}

\author{
D. Biuk, M. Vinković, S. Matić, M. Bradvica, E. Biuk i T. Benašić
}

Cilj istraživanja bio je usporediti dijagnostičke testove za konjunktivitis sicca (Schirmerov test, test raskidanja suznog filma (engl. tear break-up time test, TBUT) i testove bojanja rožnice fluoresceinom i zelenom bojom lisamin) kod bolesnika s blefarospazmom. Prospektivnom studijom obuhvaćeno je šezdeset ispitanica starijih od četrdeset godina kojima je dijagnosticiran blefarospazam. Ispitanice su podijeljene u dvije skupine ovisno o kliničkim simptomima. Površina ispod krivulje ROC za fluoresceinski test iznosila je 1,0 uz standardnu grešku (SE) 0 i interval pouzdanosti (95\% CI) 0,940-1,0; za Schirmerov test je površina ispod krivulje ROC iznosila 0,817 uz SE 0,0555 i 95\% CI 0,696-0,905; za test sa zelenom bojom lisamin površina ispod krivulje ROC bila je 0,813 uz SE 0,056 i 95\% CI 0,691-0,902; te za test TBUT je površina ispod krivulje ROC bila 0,772 uz SE 0,061 i 95\% CI 0,645-0,870. U studiji je prema rezultatima krivulje ROC, kojom se utvrđuje osjetljivost i specifičnost normalnih vrijednosti, fluoresceinski test imao najbolju osjetljivost i specifičnost u usporedbi s drugim testovima koji se primjenjuju u dijagnosticiranju suhog keratokonjunkitivitisa. Izvođenje Schirmerova testa ne preporuča se u bolesnika s keratokonjunktivitisom sicca i blefarospazmom zbog čestog treptanja, što može utjecati na rezultate testa i njegovu pravilnu interpretaciju. Unatoč patološkim brojčanim vrijednostima TBUT test je prihvatljiv za kliničku primjenu u bolesnika s keratokonjunktivitisom i blefarospazmom, jer je interval raskidanja suznog filma duži od vremenskog intervala između dva treptaja.

Ključne riječi: Bojenje i označavanje preparata; Blefarospazam; Flourescein; Lisamin, zelena boja; Krivulja ROC; Hrvatska 